\title{
Micromorphological characteristics of sandy forest soils recently impacted by wildfires in Russia
}

\author{
Ekaterina Maksimova ${ }^{1,2}$ and Evgeny Abakumov ${ }^{1,2}$ \\ ${ }^{1}$ Department of Applied Ecology, Saint Petersburg State University, St Petersburg, Russia \\ ${ }^{2}$ Institute of the Ecology of the Volga Basin, Togliatti, Russia \\ Correspondence to: Ekaterina Maksimova (doublemax@yandex.ru)
}

Received: 14 December 2016 - Discussion started: 30 January 2017

Revised: 28 March 2017 - Accepted: 29 March 2017 - Published: 25 April 2017

\begin{abstract}
Two fire-affected soils were studied using micromorphological methods. The objective of the paper is to assess and compare fire effects on the micropedological organisation of soils in a forest-steppe zone of central Russia (Volga Basin, Togliatti city). Samples were collected in the green zone of Togliatti city. The results showed that both soils were rich in quartz and feldspar. Mica was highly present in soils affected by surface fires, while calcium carbonates were identified in the soils affected by crown fires. The type of plasma is humus-clay, but the soil assemblage is plasmasilt with a prevalence of silt. Angular and subangular grains are the most dominant soil particulates. No evidence of intensive weathering was detected. There was a decrease in the porosity of soils affected by fires as a consequence of soil pores filled with ash and charcoal.
\end{abstract}

\section{Introduction}

Fire has an important impact on soil properties as identified by previous works (Certini, 2005, 2013; Guénon et al., 2013; Mataix-Solera et al., 2011; Jain et al., 2012; Bergeron et al., 2013; Dymov and Gabov, 2015; Zharikova, 2015; Maximova and Abakumov, 2015). Soil processes in post-fire soil environments are quite different from those in the soils of natural landscapes or in technogenic ones. In general, changes in morphological organisation and soil mineralogy are well known in soils after fires produced at high temperatures. After the fire, there is an accumulation of ash on topsoil (Pereira et al., 2014), leaching of some nutrients into deeper horizons (Bodi et al., 2014), an over-compaction of the surface, an ac- cumulation of crusts, and a transformation of the soil structure (Mataix et al., 2011).

Micromorphological methods are known as a useful tool for the investigation of soil transformation under natural and human-impacted conditions (Stoops, 2009). The methodology of classical micropedology provides the required in formation about soil development at the micro level, such as changes in fine earth composition and soil plasma evolution (Kubiëna, 1938, 1970; Stoops and Eswaran, 1986). These methods are widely used for the analysis of soil paleoprocesses (Sedov et al., 2013), soil restoration in post-mining environments (Abakumov et al., 2005), soil elementary process in different environments (Lebedeva et al., 2010; Abakumov et al., 2013) and the specification of soil classification aspects (Kubiëna, 1970). Micromorphological investigations related to the fire effect of soil crusts and fine earth (Greene et al., 1990) and aggregate dynamics in post-fire soil (MataixSolera et al., 2002) have been undertaken. However, the micromorphological methods have never been applied to study post-fire soil transformation in the Russian wild-fire environments. Moreover, this paper deals with a comparison of different post-fire scenarios (surface and crown fires) and provides a 5-year monitoring of fire-affected soils and ecosystems as a whole. Little research has been carried out on this topic.

The objective of this work was to characterise the micromorphological indices of microstructure transformation in soils affected by different types of wild fire, as compared to the microstructure of the mature, unaffected soil of pine forests in central Russia. 
Table 1. Morphological features and general properties of soils; \pm after the mean value means SD. Nd: no data.

\begin{tabular}{|c|c|c|c|c|c|c|c|c|c|}
\hline Horizon & $\begin{array}{r}\text { Depth, } \\
\mathrm{cm}\end{array}$ & Colour & $\begin{array}{r}\text { Soil } \\
\text { humidity, } \\
\%\end{array}$ & $\begin{array}{r}\text { Ignition } \\
\text { loss value } \\
\%\end{array}$ & $\mathrm{pH}$ & $\begin{array}{r}\text { Total organic } \\
\text { carbon, } \\
\mathrm{g} \mathrm{kg}^{-1}\end{array}$ & $\mathrm{C}_{\mathrm{ha}} / \mathrm{C}_{\mathrm{fa}}$ & $\begin{array}{r}\text { Clay } \\
\text { content, } \\
\mathrm{g} \mathrm{kg}^{-1}\end{array}$ & $\begin{array}{r}\text { Sand } \\
\text { content, } \\
\mathrm{g} \mathrm{kg}^{-1}\end{array}$ \\
\hline \multicolumn{10}{|c|}{ Surface fire } \\
\hline Apyr & $0-3$ & $10 \mathrm{YR} 3 / 2$ & $2.85 \pm 0.79$ & $5.68 \pm 0.95$ & $8.0 \pm 0.06$ & $23.1 \pm 0.27$ & $2.14 \pm 0.13$ & 20.0 & 705.0 \\
\hline AY & $5-14$ & $10 \mathrm{YR} 4 / 2$ & $1.45 \pm 0.19$ & $2.79 \pm 0.60$ & $6.2 \pm 0.32$ & $12.1 \pm 0.50$ & $1.30 \pm 0.26$ & 25.0 & 807.0 \\
\hline $\mathrm{AC}$ & $14-27$ & 7.5 YR 5/4 & $1.38 \pm 0.36$ & $1.55 \pm 1.16$ & $6.0 \pm 0.21$ & $7.5 \pm 0.48$ & nd & 26.0 & 835.0 \\
\hline $\mathrm{AC}$ & $27-36$ & 10 YR 6/4 & $1.02 \pm 0.27$ & $0.80 \pm 0.49$ & $5.8 \pm 0.21$ & $3.1 \pm 0.13$ & - & 19.0 & 852.0 \\
\hline $\mathrm{AC}$ & $36-53$ & 10 YR 6/4 & $0.98 \pm 0.42$ & $0.98 \pm 0.73$ & $5.3 \pm 0.31$ & $2.2 \pm 0.05$ & - & 24.0 & 866.0 \\
\hline $\mathrm{C}$ & $53-73$ & 7.5 YR 5/4 & $0.69 \pm 0.05$ & $0.81 \pm 0.05$ & $5.7 \pm 0.21$ & $2.4 \pm 0.10$ & - & 13.0 & 864.0 \\
\hline \multicolumn{10}{|c|}{ Crown fire } \\
\hline Apyr & $0-5$ & 10 YR 3/2 & $2.37 \pm 0.36$ & $5.45 \pm 1.41$ & $7.9 \pm 0.12$ & $31.9 \pm 0.19$ & $1.95 \pm 0.34$ & 17.0 & 720.0 \\
\hline AY & $3-10$ & $10 \mathrm{YR} 4 / 2$ & $1.43 \pm 0.35$ & $3.01 \pm 1.31$ & $5.9 \pm 0.38$ & $14.2 \pm 0.31$ & $1.18 \pm 0.11$ & 20.0 & 788.0 \\
\hline $\mathrm{AC}$ & $10-15$ & 7.5 YR 5/2 & $0.86 \pm 0.20$ & $2.91 \pm 3.01$ & $5.9 \pm 0.25$ & $7.8 \pm 0.07$ & nd & 17.0 & 852.0 \\
\hline $\mathrm{AC}$ & $15-24$ & 10 YR 7/4 & $1.11 \pm 0.63$ & $0.86 \pm 0.29$ & $5.9 \pm 0.36$ & $2.6 \pm 0.07$ & - & 6.0 & 862.0 \\
\hline $\mathrm{AC}$ & $24-44$ & 10 YR 6/3 & $0.52 \pm 0.05$ & $0.66 \pm 0.14$ & $5.7 \pm 0.12$ & $1.4 \pm 0.05$ & - & 4.0 & 867.0 \\
\hline $\mathrm{C}$ & $44-64$ & $10 \mathrm{YR} 6 / 3$ & $0.49 \pm 0.03$ & $0.63 \pm 0.09$ & $5.9 \pm 0.25$ & $1.2 \pm 0.05$ & - & 9.0 & 868.0 \\
\hline \multicolumn{10}{|c|}{ Control } \\
\hline $\mathrm{O}$ & $0-7$ & - & $5.92 \pm 2.27$ & $20.88 \pm 5.90$ & $6.5 \pm 0.10$ & nd & $1.17 \pm 0.18$ & nd & nd \\
\hline AY & $7-10$ & $10 \mathrm{YR} 4 / 2$ & $1.60 \pm 0.47$ & $2.71 \pm 1.34$ & $6.3 \pm 0.06$ & $19.4 \pm 1.35$ & $0.67 \pm 0.13$ & 21.0 & 787.0 \\
\hline AY & $10-14$ & 10 YR 6/4 & $0.78 \pm 0.15$ & $1.57 \pm 0.82$ & $6.2 \pm 0.23$ & $7.8 \pm 0.33$ & nd & 18.0 & 837.0 \\
\hline $\mathrm{AC}$ & $14-23$ & 7.5 YR 3/2 & $0.78 \pm 0.42$ & $0.66 \pm 0.50$ & $6.1 \pm 0.23$ & $3.3 \pm 0.10$ & - & 13.0 & 867.0 \\
\hline $\mathrm{AC}$ & $23-33$ & 2.5 YR 8/6 & $0.42 \pm 0.01$ & $0.57 \pm 0.12$ & $5.9 \pm 0.20$ & $1.5 \pm 0.02$ & - & 4.0 & 888.0 \\
\hline $\mathrm{C}$ & $33-50$ & 2.5 YR $8 / 6$ & $0.33 \pm 0.02$ & $0.46 \pm 0.01$ & $5.7 \pm 0.12$ & $2.1 \pm 0.03$ & - & 7.0 & 891.0 \\
\hline $\mathrm{C}$ & $50-70$ & 2.5 YR $8 / 6$ & $0.32 \pm 0.03$ & $0.52 \pm 0.17$ & $5.8 \pm 0.31$ & $1.5 \pm 0.05$ & - & 3.0 & 895.0 \\
\hline \multicolumn{10}{|c|}{ Post hoc test } \\
\hline \multirow{3}{*}{\multicolumn{2}{|c|}{$\begin{array}{l}\text { Crown control } \\
\text { Surface control } \\
\text { Crown surface }\end{array}$}} & & & & & $p<0.05$ & & $p<0.06$ & $p<0.07$ \\
\hline & & & & & & $p<0.01$ & & $p<0.04$ & $p<0.02$ \\
\hline & & & & & & $p<0.02$ & & $p<0.08$ & $p<0.09$ \\
\hline
\end{tabular}

\section{Materials and methods}

\subsection{Study area}

The study was conducted in the Samara region situated near the Volga River, in the central part of European Russia $\left(58^{\circ} 39^{\prime} 44.55^{\prime \prime} \mathrm{N}, 39^{\circ} 17^{\prime} 48.95^{\prime \prime} \mathrm{E}\right.$; 179 m a.s.l.). The extremely hot weather in the summer of 2010 in Russia (especially bad in the entire Russian European area and also Ukraine and eastern Europe) resulted in drought and eventually catastrophic forest fires in vast territories of European and Siberian Russia. The forest fire studied occurred in 2010 and affected more than 8000 ha. Fire severity was very high. The parent material is composed of old (Pleistocene) alluvial-dune landscape.

The affected ecosystem is characterised by a forest-steppe environment with higher pedo-diversity. The vegetation was composed mostly of pine forests (Pinus sylvestris L.). There are xerophyte species at dry locations like Veronica spicata L., Sedum acre L., Antennaria dioica L., Calamagrostis epigejos (L.) Roth and Centaurea marschalliana Spreng. and hardwoods (Quercus robur L., Betula pendula Roth, Populus tremula L.) in more humid conditions. The herbaceous vegetation consists of rhizomatous and loose-bunch Gramen (Bromus inermis Leyss., Elytrigia repens L., some species of Poa, and Agrostis canina L.) in post-fire plots.

A variety of Luvisols and Chernozems prevail in the watershed sections (Nosin, 1949; Vasil'eva and Baranova, 2007; Abakumov and Gagarina, 2008; Abakumov et al., 2009; Urusevskaja et al., 2000; Saksonov, 2006), whereas Calcaric Chernozems (southern type) dominate in the south of the region (steppe zone of the Samara region), accompanied by some polypedons of Kastanozems (Nosin, 1949). The soils of investigated area are sandy and sandy loam textured. In the studied area, soils were classified as sandy loam soils on Late Pleistocene alluvial Volga sands - Protoargic Arenosols according to World Reference Base (2015) and to Shishov and Tonkonogov (2004) - and they have weak features of illuvial phenomena without the formation of separate horizons. The 


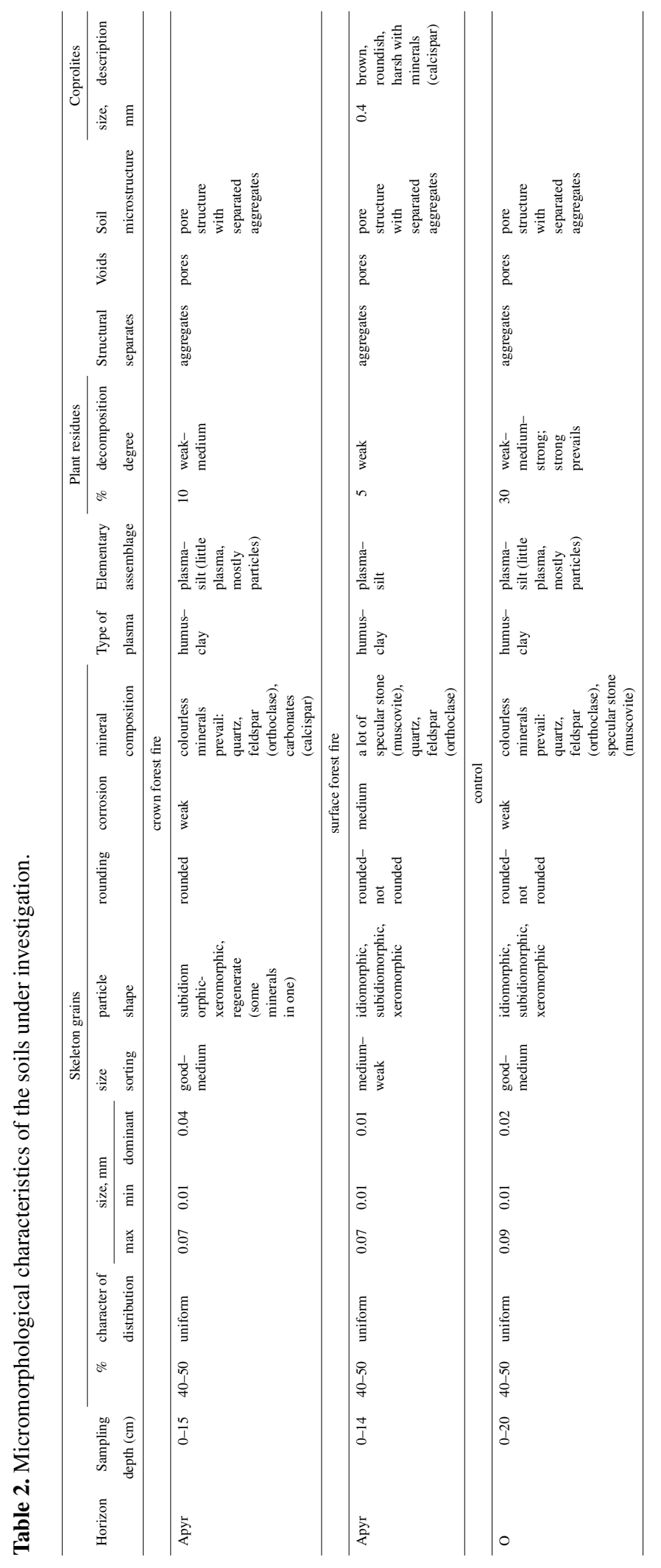

sand content in these soils is $70.5-86.4 \%$; their clay content is $0.3-2.6 \%$.

Three soil pits were sampled in two different fire-affected areas: one at a site affected by a surface forest fire and another affected by a crown fire. A sample was collected in an unburnt area to serve as control. Soil types and vegetation were the same. Soils were sampled as fast as possible after the removal of a state of emergency from the territory in the summer of 2010 and also during the period 20112015. Three soil pits were sampled in each studied area. The general characteristics of the soils, including the chemical and physical parameters, were determined by standard methods (Methods of Soil Analysis, 1996). The measurements of these soil properties were performed in triplicate. The normal distribution of the data was verified previously, and analysis of variance (ANOVA) and a post hoc test were conducted using SIGMAPLOT 8.0 software with the aim of comparing differences between plots (site effect). Differences were considered significant at $p<0.05$. Undisturbed and post-pyrogenic soil samples were collected in 2011 using Kubiëna-type boxes $5 \times 3.5 \times 1.5 \mathrm{~cm}$ in size at the depth of $0-10 \mathrm{~cm}$ and taken to the laboratory.

\subsection{Micromorphological analysis}

Soil samples were air-dried and passed through a $1 \mathrm{~mm}$ sieve. Fine sections of soil material were prepared from micro monoliths of soils, sampled in field. Samples were dried and saturated with resin.

Thin sections were investigated with use of a polarisation microscope (Leica DFC 320) in transmitted light and crossed nicols. The following soil micromorphological indexes were investigated: soil microfabric, spatial arrangements of fabric units, soil particle distribution, elements of microstructure and character of organic matter. The terminology used in this paper is published by Stoops (2003), Gagarina (2004) and Gerasimova et al. (2011), where details of the micro organisation of soil were described in detail.

\section{Results and discussion}

\subsection{Soil profile analysis and physico-chemical properties}

The soil profile organisation can be described as Apyr (or O in the case of control) - AY - AC - C. The Apyr horizon is a black layer due the deposition of an ash and charcoal at the soil surface, unlike that observed in the control plot (Figs. 1, $2,3)$. A wide distribution of coal pieces, a total absence of forest floor remnants and its transformation into ash were diagnosed in 2010 immediately after the fires. At the beginning of the research (2010), thick black horizons were observed at the soil surface, while in the summer of 2011, they were only present as a thin layer at the surface. This testifies to the influence on erosion, as the soil surface was affected by pre- 


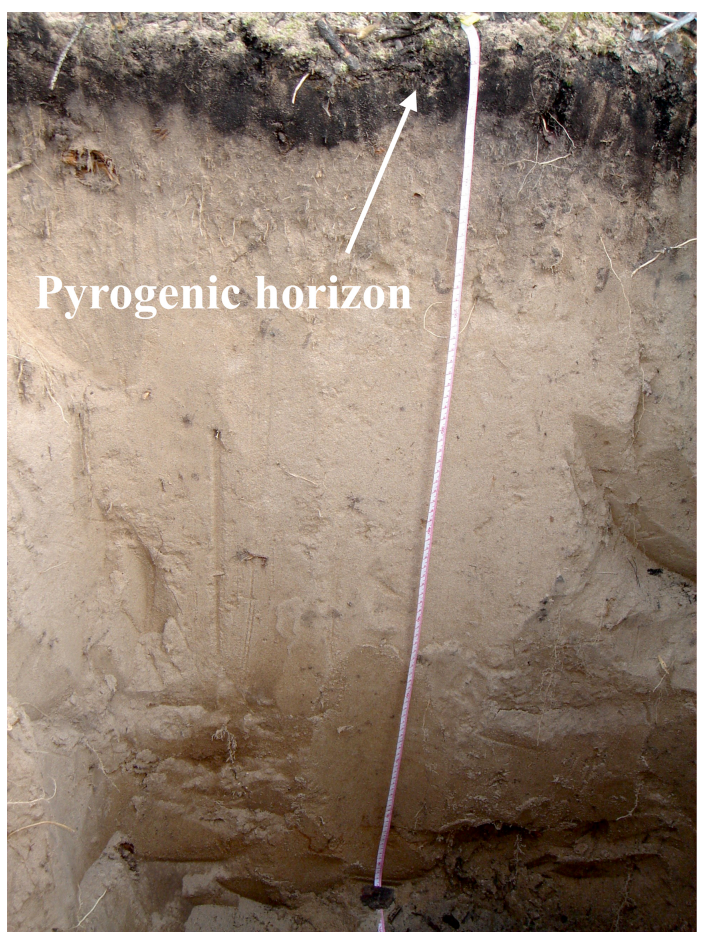

Figure 1. Crown fire-affected soil.

cipitation after the disappearance of forest floor (Robichaud, 2005; Vieira et al., 2014; Delwiche, 2009).

Data on the general characteristics of the soils are given in Table 1.

Organic matter is lost from the surface horizons of the soil, which is related to the destruction of the organic horizons, the mineralisation of root residues and the almost complete absence of fresh plant waste, which could be a material for humification. Humus degradation of the upper horizons was clearly visible by means of the ignition loss value. Ignition loss was more than $20.00 \%$ in the upper layer in the control plot (Table 1), but only $5.45 \%$ in the crown fire and $5.68 \%$ in the surface fire plots. In 2010, the content of organic matter in the ash at the soil surface after the surface fire $(2.31 \pm 0.27 \%)$ was lower than that after the crown fire $(3.19 \pm 0.19 \%)$. A similar tendency was observed in the pyrogenically transformed humus-enriched horizons: the content of organic carbon was $1.21 \pm 0.50 \%$ after the surface fire and $1.42 \pm 0.31 \%$ after the crown fire. Thus, a surface fire, which leads to the complete burning out of the litter and the upper horizons, results in larger losses of organic matter.

The acidity in the upper horizons of the burnt soils decreases significantly, and the burnt litters have an alkaline reaction ( $\mathrm{pH} 7.9-8.0$ ), while the lower horizons have a weakly acidic reaction close to that in the corresponding horizon of the undisturbed forest soil ( $\mathrm{pH}$ 5.7-5.9). The increase in the $\mathrm{pH}$ values of the soils after fires is related to the fact that the water-soluble ash components penetrate into the soil and saturate the soil exchange complex with alkaline-earth el-

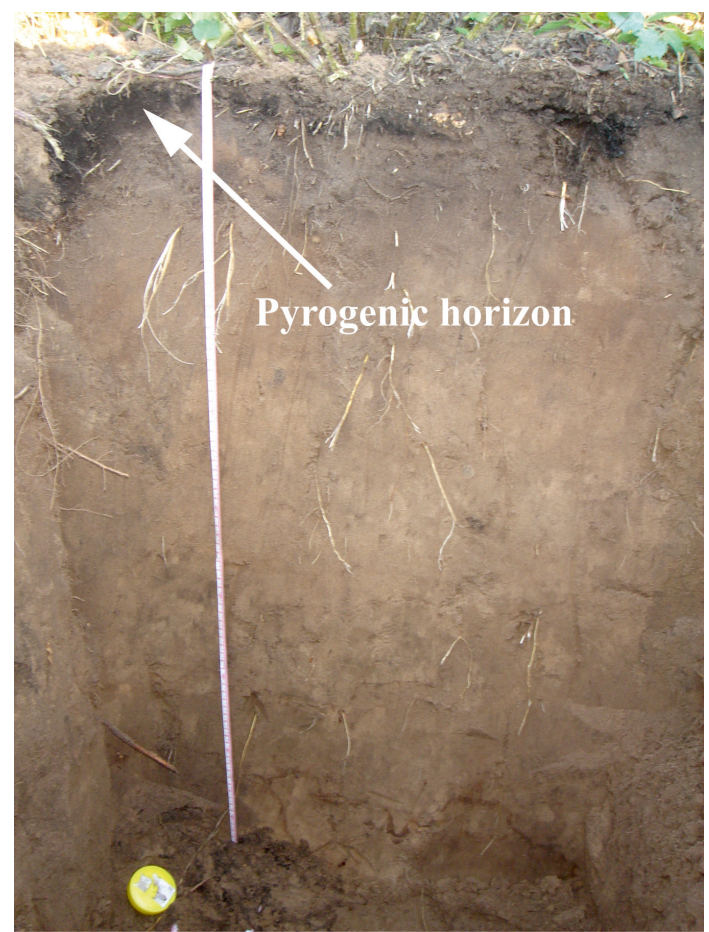

Figure 2. Surface fire-affected soil.

ements, which shifts the reaction toward the neutral value. No differences in the $\mathrm{pH}$ changes between the effects of the crown and surface fires were observed in the first year of the study. The reaction of the parent rock is similar in all three plots and is characterised as weakly acidic. The partial or sometimes complete mineralisation of organic residues because of pyrolysis resulted in the synchronous input of ash elements onto the soil surface and into the litter, which neutralised the organic acids arriving in the soil solution during the decomposition of the litters. It is therefore obvious that the higher the ash yield (i.e. the more intensive the fire), the more complete and active the neutralisation of the litters.

The group humus composition $\left(\mathrm{C}_{\mathrm{ha}}\right.$ to $\mathrm{C}_{\mathrm{fa}}$ ratio) of the upper soil layers changed as a result of the fires (Table 1). Some authors have noted an increase in humic acid content and a decrease in the carbon-to-nitrogen ratio (Abakumov and Frouz, 2009; Efremova and Efremov, 2006). By contrast, the appearance of the most aggressive fractions presented by fulvic acids was recorded in other studies (Dobrovol'skij, 2002). In our case, the litter of the control plot was characterised by a fulvic-humic type of humus (for the other horizons, humic-fulvic) and an increase in humic acids, which was especially strong after the surface fire, as is characteristic for post-pyrogenic soils. A reduction in the $\mathrm{C}_{\mathrm{ha}} / \mathrm{C}_{\mathrm{fa}}$ ratio due to new plant litter was observed in the following years. An increase in humic acid content was also observed in the humus horizon.

A year after the fire, the $\mathrm{pH}$ of the burnt litters decreased from 7.9-8.0 (in 2010) to 6.4-6.6 (in 2011), and its absolute 


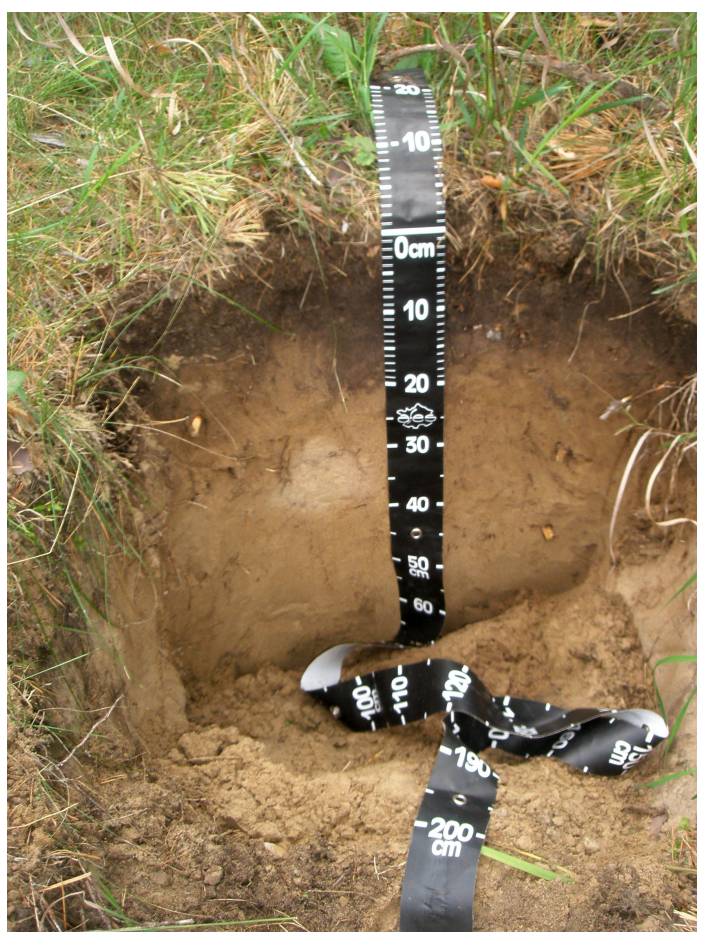

Figure 3. Control soil.

values approached the control level. This is easily explicable: rain and snowmelt waters almost completely removed the soluble ash components for a year; i.e. the alkali elements were removed from the ash at the fire sites.

A post hoc test has shown that significant differences were revealed for the carbon content between surface fire and crown fire $(p<0.02)$, between control and crown fire $(p<0.05)$ and also between control and surface fire plots $(p<0.01)$. As for the silt and clay fraction, there were differences only between control and surface fires $(p<0.04)$. The same situation was characteristic of the sand fraction $(p<0.02)$.

The WRB system (World Reference Base, 2015) does not have any horizons or diagnostic parameters of pyrogenic soils. But the WRB system has pretic horizon as being dark, with a high content of organic matter and phosphorus, low biological activity, and high contents of exchangeable calcium and magnesium, with remnants of charcoal and/or artefacts. A pyrogenic horizon with an abundance of charcoal is formed after wildfires. It can resist degradation when vegetation has not started to recover yet at burnt places and charcoal has not started to be redistributed while erosion and infiltration are in progress. However, black carbon decomposition is controversial, and there are different views on this issue. Some studies argue that black carbon decomposes very slowly (Liu et al., 2008) or is practically non-degradable (González-Pérez et al., 2004), while others show that it is successfully affected by chemical (Cheng et al., 2006, 2008) and microbial (Knicker et al., 2013; Marschner et al., 2008) oxidation. The assumption of black carbon complete stability in soils is doubtful because its content varies considerably in different soils. This is explained not only by a difference in pyrogenic activity in different natural zones, but also by a difference in humidity (Nguyen and Lehmann, 2009) and temperature (Cheng et al., 2008; Nguyen et al., 2010), by various physical and chemical soil characteristics, by different biological activity, and by land use practices (Czimczik and Masiello, 2007).

\subsection{Micromorphological characteristics}

Differences in post-pyrogenic and unburnt soils are shown well in the morphological, chemical, physical and biological properties of horizon A. The morphological organisation of solum in burnt soils differs from that in unburnt soils in a number of parameters: wide distribution of charcoal pieces; absence of litter and its transformation into ash that is a mix of mineral soil components, burnt-down plant residues, and small pieces of charcoal (Bodi et al., 2014; Pereira et al., 2014,2015 ); and likewise a reduction in the humic horizon's depth. There is soil erosion because of rainfall; this is characterised by a decrease in black surface horizon thickness after several years of investigation as observed in earlier studies (Francos et al., 2016).

Data on soil micromorphological features are presented in Table 2 and Fig. 4. The results showed that the elementary assemblage of crown fire soil is plasma-silt (with a small proportion of plasma and a prevalence of silt particles). In the case of the soil affected by surface fire, the type of assemblage is plasma-silt, which is a result of the accumulation of humus-type organic matter. In both cases the type of the plasma is classified as humus-clay. The structure of all three soils investigated is crumbly, inherited from the previous stages of soil formation. There are no evident features of mass aggregation in the fire-affected soils. The type of the microstructure of all the soils is angular blocky or subangular blocky, which is caused by a low intensity of current weathering in soil mass. The particle shape is subidiomorphic or idiomorphic in cases investigated with weak or medium degree of corrosion.

The mineral composition of the soils can be described as follows: uncoloured minerals, quartz, orthoclase and carbonates (crown fire); quartz and orthoclase with many crystals of muscovite and an absence of carbonates (surface fire); and a predominance of uncoloured minerals with quartz and muscovite in the case of the control plot. The possibility of new mineral formation under the strong heating effect has been reported in previous works (Nobles, 2010; Leon et al., 2014); however, carbonate accumulation does not result from the heating process in the crown fire scenario. In some arrangements, soil microstructure can be classified as skeletal, which is caused by a high content of non-weathered soil particles. No evidence of current weathering (alteration) has been found, but some pore infilling was recognised as a result 


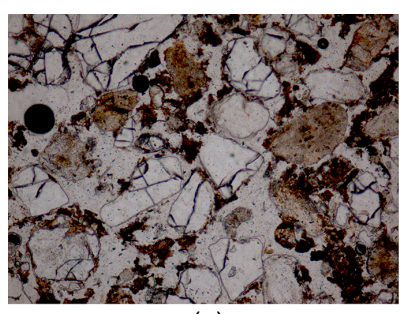

(a)

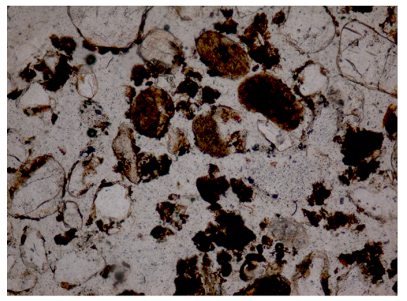

(c)

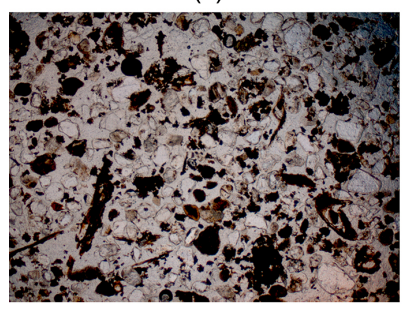

(e)

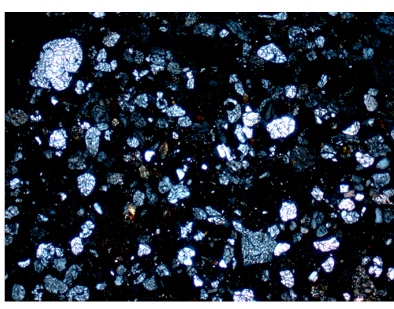

(b)

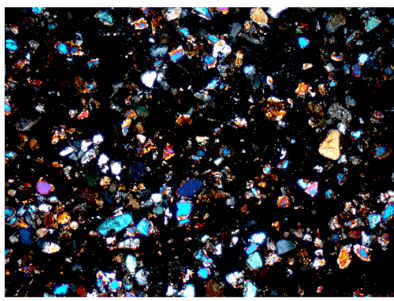

(d)

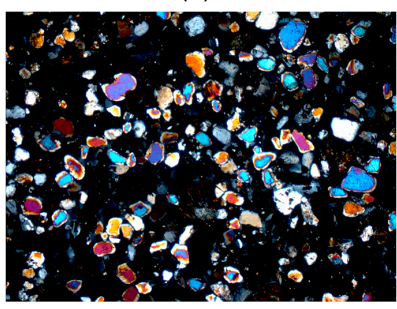

(f)

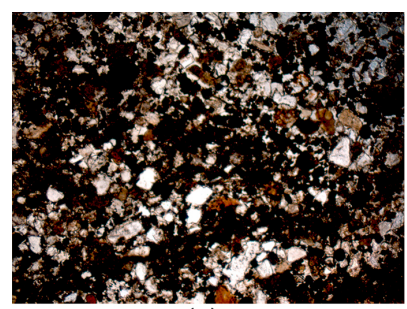

(a)

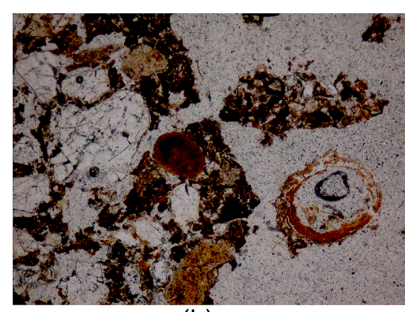

(b)

Figure 5. (a) Humons (organic particles with non-humified organic matter), transmitted light; (b) organic tissue of non-decomposed remnants.

The type of fire affected the soil organic micromorphology. The quantity of non-humified organic matter in the burnt soils, especially in the samples affected by surface fire, was identified as increased in burnt soils (Fig. 5a). It is also evident that the size of organic residues is higher in fire-affected soils than in mature ones. In mature soils the transformation and humification of organic matter are a gradual process, while new, relatively fresh non-decomposed organic matter has come into the upper soil horizons in fire-affected areas (Gagarina, 2004).

\section{Conclusions}

Figure 4. Thin sections. (a, b) Crown fire; (c, d) surface fire; (e, f) nature plot. Left column - transmitted light; right column crossed nicols.

of ash, charred material and erosion particles accumulating in fire-affected soils (Fig. 5). Non-decomposed organic tissue and residue infill the porous media in these soils. This is the result of an increment of raw forms of organic material in burnt soils. Organic matter under the effect of fire was polymorphic (Fig. 5a, b; Stoops, 1986), while it is monomorphic in the soils of the control plot. The porous media infilling after the fires was described previously by Nobles (2010); however, in this case, it was an accumulation of $\mathrm{Mn}-\mathrm{Fe}$-enriched materials. Balfour and Woods (2007) observed similar results in fire-affected soils. So, taking our data into account it is possible to conclude that the infilling of porous media by material of a different composition is typical in burnt soils. Decreasing the porous media area was also described as being the result of an accumulation of ash (Balfour and Woods, 2007), and this explanation of porous media infilling is more appropriate to our case. The investigated soils are characterised by developed system of porous media; this is important regarding the heat penetration into soil and soil resistance to heating. The soils investigated are not as resistant to heating as clay texture ones, where the porous media are not as developed. Pores, cracks and other spaces make it possible for the combustion products to penetrate into the soil and affect the polycyclic aromatic hydrocarbons (PAHs) and other product accumulations.

The 2010 catastrophic natural fires in the urban forests of Togliatti resulted in the formation of pyrogenically transformed soils, the morphological parameters and the main chemical and physical properties of which significantly differ from those of the undisturbed soils.

The burnt soils differ from the control soil on the macromorphological level only in the upper part of the profile, where the litter is transformed to ash which is identified as a dim grey organomineral mixture. Processes of soil erosion are clearly manifested 1 year after the fire under the effect of precipitation and the illuviation of organic matter to the medium part of the profile, and they will probably continue for several years.

The fires significantly affect the physicochemical and chemical properties of the soils. However, the effect of fires on the properties of the studied soils usually does not spread deeper than $10 \mathrm{~cm}$.

The results of this work showed that mineral composition of all the soils studied consists of quartz and feldspar (orthoclase); in the case of a surface forest fire there was more mica (muscovite), and calcium carbonates appeared in soils affected by crown forest fire. The reasons for this compound accumulation are still not well understood. The type of plasma is humus-clay, but the soil assemblage is plasma-silt, with a prevalence of silt. Angular and subangular grains form the main soil carcass, and no evidence of intensive weathering alteration has been revealed. At the same time, a decrease in the porous media was recognised as the main soil 
development process after the fires. This is the result of soil porous infilling by ash and charred organic material of different nature: some organic remnants (tissue) come into the porous media after fire, and some transformed, coaled and dark coloured parts also appear in post-fire horizons. Partially decomposed fire-affected particles of soil organic matter accumulate in post-fire soils, especially in porous soil media, which is a result of the soil organic matter accumulation and transformation in post-fire environments.

Data availability. No data sets were used in this article.

Competing interests. The authors declare that they have no conflict of interest.

Acknowledgements. The authors thank the director of the Institute of the Ecology of the Volga River Basin of the Russian Academy of Sciences (IEVB RAS), G. S. Rosenberg; the deputy director for science of IEVB RAS, S. V. Saksonov; S. A. Senator for the help in the organisation of work and research support; and Rita Lazareva for her kind assistance with thin section description.

This work was supported by the Russian Foundation for Basic Research, projects 14-04-32132, 15-34-20844, Saint Petersburg University grant No. 1.37.151.2014 and Saint Petersburg State University Internal Grant for the Modernisation of Scientific Equipment No. 1.40.541.2017.

Edited by: A. Jordán

Reviewed by: A. Tsibart and one anonymous referee

\section{References}

Abakumov, E. V., Gagarina, E. I., and Lisitsyna, O. V.: Land reclamation in the Kingisepp area of phosphorite mining, Eurasian Soil Sci., 38, 648-655, 2005.

Abakumov, E. V., Fujitake, N., and Kosaki, T.: Humus and humic acids of Luvisol and Cambisol of Jiguli ridges, Samara Region, Russia, Appl. Environ. Soil Sci., 671359, 2009.

Abakumov, E. V., Gagarina, E. I., Sapega, V. F., and Vlasov, D. Y.: Micromorphological features of the fine earth and skeletal fractions of soils of West Antarctica in the areas of Russian Antarctic stations, Eurasian Soil Sci., 46, 1219-1229, 2013.

Balfour, V. and Woods, S. W.: Does wildfire ash block soil pores? A micromorphological analysis of burned soils, American Geophysical Union, Fall Meeting, abstract no. H43F-1695, 2007.

Bergeron, S. P., Bradley, R. L., Munson, A., and Parsons, W.: Physico-chemical and functional characteristics of soil charcoal produced at five different temperatures, Soil Biol. Biochem., 58, 140-146, 2013.

Bodi, M., Martin, D. A., Santin, C., Balfour, V., Doerr, S. H., Pereira, P., Cerda, A., and Mataix-Solera, J.: Wildland fire ash: production, composition and eco-hydro-geomorphic effects, Earth-Sci. Rev., 130, 103-127, 2014.
Certini, G.: Effects of fire on properties of forest soils: a review, Oecologia, 143, 1-10, 2005.

Certini, G.: Fire as a soil-forming factor, Ambio, 43, 191-195, doi:10.1007/s13280-013-0418-2, 2013.

Cheng, C. H., Lehmann, J., and Engelhard, M. H.: Natural oxidation of black carbon in soils: Changes in molecular form and surface charge along a climosequence, Geochim. Cosmochim. Ac., 72, 1598-1610, 2008.

Cheng, C.-H., Lehmann, J., Thies, J. E., Burton, S. D., and Engelhard, M. H.: Oxidation of black carbon by biotic and abiotic processes, Org. Geochem., 37, 1477-1488, 2006.

Czimczik, C. I. and Masiello, C. A.: Controls on black carbon storage in soils, Global Biogeochem. Cy., 21, GB3005, doi:10.1029/2006gb002798, 2007.

Delwiche, J.: Post-fire soil erosion and how to manage it, JFSP Briefs, Paper 59, 2009.

Dobrovol'skii, G. V.: Degradation and Conservation of Soils, Izd. Mosk. Gos. Univ., Moscow, Moscow, 2002 (in Russian).

Dymov, A. A. and Gabov, D. N.: Pyrogenic alterations of Podzols at the North-east European part of Russia: Morphology, carbon pools, PAH content, Geoderma, 241-242, 230-237, 2015.

Efremova, T. T. and Efremov, S. P.: Pyrogenic transformation of organic matter in soils of forest bogs, Eur. Soil Sci., 39, 12971305, 2006.

Francos, M., Pereira, P., Alcaniz, M., Mataix-Solera, J., and Ubeda, $\mathrm{X}$. Intense rainfall impact on soil properties in fire affected areas, Science Total Environ., 572, 1353-1362, 2016.

Gagarina, E. I.: Micromorphological method of soil investigation, S-Petersburg, 156 pp., 2004.

Gerasimova, M. I., Kovda, I. V., Lebedeva, M. P., and Tursina, T. V.: Micromorphological terms: the state of the art in soil microfabric research, Eurasian Soil Sci., 44, 804-817, 2011.

González-Pérez, J. A., González-Vila, F. J., Almendros, G., and Knicker, H.: The effect of fire on soil organic matter - A review, Environ. Int., 30, 855-870, 2004.

Greene, R. S. B., Chartres, C. J., and Hodgkinson, K. C.: The effects of fire on the soil in a degradet semiarid woodland I. Cryptogam cover and physical and micromorpological properties, Aust. J. Soil Res., 28, 755-777, 1990.

Guénon, R., Vennetier, M., Dupuy, N., Roussos, S., Pailler, A., and Gros, R.: Trends in recovery of Mediterranean soil chemical properties and microbial activities after infrequent and frequent wildfires, Land Degrad. Dev., 24, 115-128, doi:10.1002/ldr.1109, 2013.

Jain, T. B., Pilliod, D. S., Graham, R. T., Lentile, L. B., and Sandquist, J. E.: Index for characterizing post-fire soil environments in temperate coniferous forests, Forests, 3, 445-466, doi:10.3390/f3030445, 2012.

Knicker, H., Hilscher, A., de la Rosa, J. M., González Pérez, J. A., and González-Vila, F. J.: Modification of biomarkers in pyrogenic organic matter during the initial phase of charcoal biodegradation in soils, Geoderma, 197-198, 43-50, 2013.

Kubiëna, W. L.: Micropedology, Ames, Iowa: Collegiate press, 243 pp., 1938.

Kubiëna, W. L.: Micromorphological features of Soil geography, New Jersey: Rutgers University Press, 254 pp., 1970.

Lebedeva, M., Gerasimova, M., and Golovanov, D.: Systematization of the topsoil fabrics in soils of the arid lands in northwest of central Asia, World Congress of Soil Science, Soil Solutions 
for a Changing World (1-6 August 2010), Brisbane, Australia, Published on DVD, 96, 2010.

León, J., Seeger, M., Badía, D., Peters, P., and Echeverría, M. T.: Thermal shock and splash effects on burned gypseous soils from the Ebro Basin (NE Spain), Solid Earth, 5, 131-140, doi:10.5194/se-5-131-2014, 2014.

Liu, G., Niu, Z., Niekerk, D., Xue, J., and Zheng, L.: Polycyclic aromatic hydrocarbons (PAHs) from coal combustion: emissions, analysis, and toxicology, Rev. Environ. Contam. Toxicol., 192, 1-28, 2008.

Maksimova, E. and Abakumov, E.: Wildfire effects on ash composition and biological properties of soils in forest-steppe ecosystems of Russia, Environ. Earth Sci., 74, 4395-4405, doi:10.1007/s12665-015-4497-1, 2015.

Marschner, B., Brodowski, S., Dreves, A., Gleixner, G., Gude, A., Grootes, P. M., Hamer, U., Heim, A., Jandl, G., Ji, R., Kaiser, K., Kalbitz, K., Kramer, C., Leinweber, P., Rethemeyer, J., Schäffer, A., Schmidt, M. W. I., Schwark, L., and Wiesenberg, G. L. B.: How relevant is recalcitrance for the stabilization of organic matter in soils?, J. Plant Nutr. Soil Sci., 171, 91-110, 2008.

Mataix-Solera, J., Gomez, I., Navarro-Perdenno, J., Guerrero, C., and Moral, R.: Soil organic matter and aggregates affected by wildfire in a Pinus halepensis forest in a Mediterranean environment, Int. J. Wildland Fire, 11, 107-114, 2002.

Mataix-Solera, J., Cerdà, A., Arcenegui, V., Jordán, A., and Zavala, L. M.: Fire effects on soil aggregation: a review, Earth-Sci. Rev., 109, 44-60, doi:10.1016/j.earscirev.2011.08.002, 2011.

Methods of Soil Analysis: Soil Science Society of America Inc., Wisconsin, USA, Part 3 Chemical Methods. Wisconsin, USA: Soil Science Society of America Inc., American Society of Agronomy Inc. 677, South Segoe Road, Madison, 1996.

Nguyen, B. T. and Lehmann, J.: Black carbon decomposition under varying water regimes, Org. Geochem., 40, 846-853, 2009.

Nguyen, B. T., Lehmann, J., Hockaday, W. C., Joseph, S., and Masiello, C. A.: Temperature sensitivity of black carbon decomposition and oxidation, Environ. Sci. Technol., 44, 3324-3331, 2010.

Nobles, M. M.: Mineralogical and micromorphological modification in soil affected by slash pile burn, Abstracts of IV International conference on Forest Fire Research (15-18 November 2010), Coimbra, Potugal, 2010.

Nosin, V. A. et al.: Soils of Kujbyshev region, OGIZ, Kujbyshev, 383 pp., 1949.

Pereira, P., Úbeda, X., Mataix-Solera, J., Oliva, M., and Novara, A.: Short-term changes in soil Munsell colour value, organic matter content and soil water repellency after a spring grassland fire in Lithuania, Solid Earth, 5, 209-225, doi:10.5194/se-5-209-2014, 2014.
Pereira, P., Cerdà, A., Úbeda, X., Mataix-Solera, J., Arcenegui, V., and Zavala, L.: Modelling the impacts of wildfire on ash thickness in a short-term period, Land Degrad. Dev., 26, 180-192, 2015.

Robichaud, P. R.: Measurement of post-fire hillslope erosion to evaluate and model rehabilitation treatment effectiveness and recovery, Int. J. Wildland Fire, 14, 475-485, 2005.

Saksonov, S. V.: Samarskaya Luka flora phenomenon, Moscow: Science, 263 pp., 2006.

Sedov, S. N., Sycheva, S., Targulian, V., Pi, T., and Diaz, J.: Last Interglacial paleosols with Argic horizons in upper Austria and Central Russia - pedogenetic and paleoenvironmental inferences from comparison with Holocene analogues, Quaternary Sci. J., 62, 44-58, 2013.

Shishov, L. L. and Tonkonogov, V. D.: Classification and diagnostics of Russian soils, Moscow, Russia: Soil institute of Dokuchayev, 341 pp., 2004.

Stoops, G.: Guidelines for analysis and description of soil and regolith thin section, Published by soil Sci. Soc. Am. Inc. Madison, Wisconsin, USA, 184 pp., 2003.

Stoops, G.: Evaluation of Kubiena's contribution to micropedology. At the Occasion of the Seventieth Anniversary of His book "Micropedology", Eurasian Soil Sci., 42, 693-698, 2009.

Stoops, G. and Eswaran, H.: Soil micromorphology, New York: Van Nostrands Reinhold Company, 345 pp., 1986.

Urusevskaja, I. S., Meshalkina, J. L., and Hohlova, O. S.: Geographic and genetic features of luvisols' humus status, Eur. Soil Sci., 11, 1377-1390, 2000.

Vasil'eva, D. I. and Baranova, M. N.: Natural resources of Samara region, Samara municipal managment institute, Samara, 40 pp., 2007.

Vieira, A., Bento-Gonçalves, A., Lourenço, L., Nunes, A., MeiraCastro, A., and Ferreira-Leite, F.: Soil erosion after forest fires: evaluation of mitigation measures applied to drainage channels in the northwest of Portugal, FLAMMA, 5, 127-129, 2014.

World reference base for soil resources: International soil classification system for naming soils and creating legends for soil maps, 2014, FAO, Rome, 2015.

Zharikova, Y. A.: Post-pyrogenic soil transformation in the forests of the lower Amur region, Bulletin of Altai state agricultural university, 8, 57-61, 2015. 